\title{
Ideas of monarchical reform
}

Fénelon, Jacobitism and the political works of the Chevalier Ramsay

\section{ANDREW MANSFIELD}

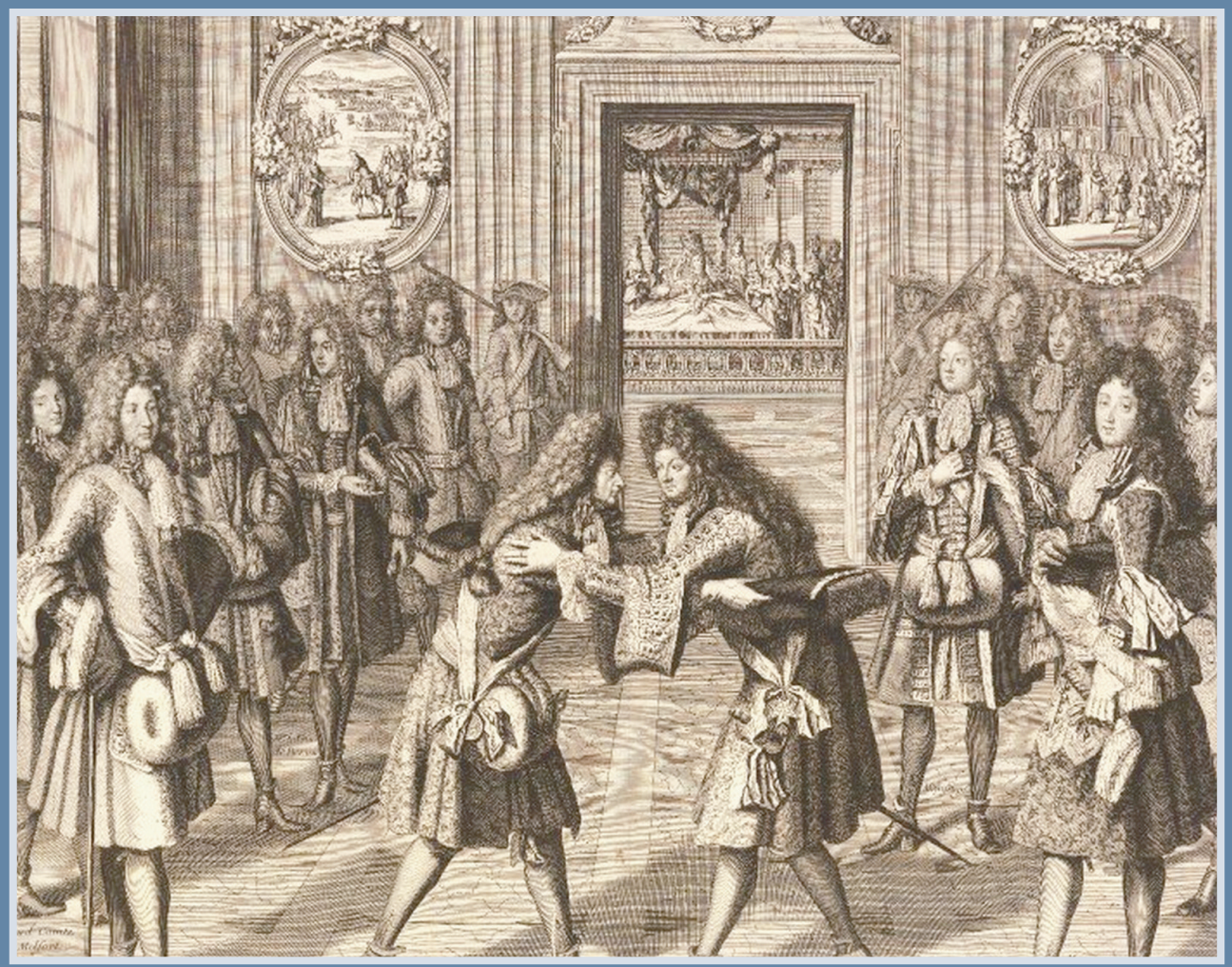




\section{Ideas of monarchical reform}

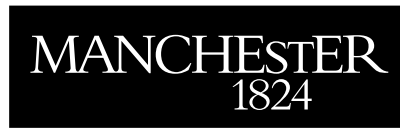

Manchester University Press 


\section{STUDIES IN EARLY MODERN EUROPEAN HISTORY}

This series aims to publish

challenging and innovative research in all areas of early modern continental history.

The editors are committed to encouraging work

that engages with current historiographical debates, adopts an interdisciplinary approach, or makes an original contribution to our understanding of the period.

SERIES EDITORS

Joseph Bergin, William G. Naphy, Penny Roberts and Paolo Rossi

Also available in the series Jews on trial:The papal inquisition in Modena, 1598-1638 Katherine Aron-Beller

Sodomy in early modern Europe ed. Tom Betteridge

Princely power in the Dutch Republic:

Patronage and William Frederick of Nassau (1613-64)

Geert H. Janssen, trans. J. C. Grayson

Representing the King's splendour: Communication and reception of symbolic forms of power in viceregal Naples

Gabriel Guarino

The English Republican tradition and eighteenth-century France: between the ancients and the moderns Rachel Hammersley

Power and reputation at the court of Louis XIII: the career of Charles d'Albert, duc de Luynes (1578-1621) Sharon Kettering

Absolute monarchy on the frontiers: Louis XIV's military occupations of Lorraine and Savoy Phil McCluskey

Catholic communities in Protestant states: Britain and the Netherlands c.1570-1720 eds Bob Moore, Henk van Nierop, Benjamin Kaplan and Judith Pollman

Orangism in the Dutch Republic in word and image, 1650-1675

Jill Stern

The great favourite: the Duke of Lerma and the court and government of Philip III of Spain, 1598-1621

Patrick Williams

Full details of the series are available at www.manchesteruniversitypress.com 


\section{Ideas of monarchical reform}

Fénelon, Jacobitism and the political works of the Chevalier Ramsay

ANDREW MANSFIELD

Manchester University Press 
Copyright (C) Andrew Mansfield 2015

The right of Andrew Mansfield to be identified as the author of this work has been asserted by him in accordance with the Copyright, Designs and Patents Act 1988

Published by Manchester University Press

Altricham Street, Manchester M1 7JA, UK

www.manchesteruniversitypress.co.uk

British Library Cataloguing-in-Publication Data

A catalogue record for this book is available from the British Library

Library of Congress Cataloging-in-Publication Data applied for

\section{ISBN 9780719088377 hardback}

First published 2015

The publisher has no responsibility for the persistence or accuracy of URLs for any external or third-party internet websites referred to in this book, and does not guarantee that any content on such websites is, or will remain, accurate or appropriate.

Typeset in Perpetua with Albertus display by Koinonia, Manchester 